\title{
Incidence of myocardial infarction in low-income urban residents of Mexico City
}

\author{
Aida Jiménez-Corona, MD, PhD('), Ruy López-Ridaura, MD, PhD('),Clicerio González-Villalpando, MD. ${ }^{(1,2)}$
}

Jiménez-Corona A, López-Ridaura R, González-Villalpando C. Incidencia de infarto al miocardio en residentes de nivel socioeconómico bajo de la Ciudad de México. Salud Publica Mex 2009;5 I:458-464.

\begin{abstract}
Objective. To estimate the incidence of myocardial infarction (MI) in a low-income Mexican population. Material and Methods. A total of I 696 men and women aged 35 to 64 years from a longitudinal study were included. All subjects were free of $\mathrm{Ml}$ at baseline. Incident $\mathrm{Ml}$ was diagnosed during follow-up by electrocardiogram or by death certificate. Multiple logistic regression was used to estimate the risk of MI. Results. Median follow-up was 6.2 years. Sixty-two of the participants developed MI.Age-adjusted incidence of MI was 6.6 in men and 4.8 in women per 1000 person-years. The risk of developing $\mathrm{Ml}$ was associated diabetes $(O R=2.42, p=0.003)$, systolic blood pressure $(O R=1.28$ per $10 \mathrm{~mm} \mathrm{Hg}, p=0.013)$ and serum cholesterol $(O R=1.36$ per $50 \mathrm{mg} / \mathrm{dL}, p=0.038)$. Conclusions. Incidence of $\mathrm{Ml}$ in this population may be explained by the rising prevalence of diabetes and hypercholesterolemia. It is necessary to implement preventive measures to address those risk factors.
\end{abstract}

Key words: myocardial infarction; electrocardiography; incidence; mortality; Mexico
Jiménez-Corona A, López-Ridaura R, González-Villalpando C. Incidence of myocardial infarction

in low-income urban residents of Mexico City.

Salud Publica Mex 2009;5 I:458-464.

\section{Resumen}

Objetivo. Estimar la incidencia de infarto al miocardio (IM) en población mexicana de nivel socioeconómico bajo. Material y métodos. Estudio longitudinal de 1696 hombres y mujeres de 35 a 64 años de edad y sin IM basal. IM fue definido por electrocardiograma o certificado de defunción. El riesgo de IM se evaluó con regresión logística múltiple. Resultados. Durante el seguimiento (mediana de 6.2 años) 62 participantes desarrollaron IM o murieron por éste. La incidencia de IM ajustada por edad en hombres y mujeres fue de 6.6 y 4.8 por I 000 años-persona, respectivamente. El riesgo de IM estuvo asociado con diabetes $(R M=2.42, p=$ $0.003)$, presión arterial sistólica $(R M=1.28$ por cada $10 \mathrm{~mm}$ $\mathrm{Hg}, p=0.013)$ y colesterol total $(R M=1.36$ por cada $50 \mathrm{mg} /$ $\mathrm{dL}, p=0.038)$. Conclusiones. La incidencia de IM en esta población, puede ser debida a la alta prevalencia de diabetes y colesterol elevado. Es necesario tomar medidas preventivas para disminuir estos factores de riesgo.

Palabras clave: infarto al miocardio; electrocardiografía; incidencia; mortalidad; México

(I) Instituto Nacional de Salud Pública. Cuernavaca, Morelos, México

(2) Centro de Estudios en Diabetes AC. México DF, México

Received on: April 15, 2009 • Accepted on: August 14, 2009

Address reprint requests to: Dra. Aida Jiménez-Corona. Centro de Investigación en Salud Poblacional, Instituto Nacional de Salud Pública. Av. Universidad 655, col. Santa María Ahuacatitlán. 62100, Cuernavaca, Morelos, México.

E-mail: ajimenez@correo.insp.mx 
$\mathrm{T}_{\mathrm{t}}^{\mathrm{s}}$ he incidence of coronary heart disease (CHD), particularly myocardial infarction (MI), has increased in most regions of the world over the past decades. This trend is associated with a mounting prevalence and incidence of classic cardiovascular risk factors such as obesity, diabetes, dyslipidemia, hypertension, and smoking, among others. ${ }^{1-3}$ The combination of those risk factors affects modern westernized societies by increasing the likelihood of death from cardiovascular diseases. ${ }^{4,5}$ Little is known about the incidence of MI in the general population, but available data strongly support the concept of a rising epidemic. Prevalence of associated cardiovascular risk factors is very high; mortality figures show an increase of significant proportion, and information on the incidence of MI in population-based studies confirm the high prevalence rates. ${ }^{1,4}$ Therefore, estimations of the incidence of MI and its predictors are of strategic value to design clearly indicated interventions proved useful in some populations. This study aimed at evaluating the incidence of $\mathrm{MI}$ in a low-income Mexican population and at quantifying its association with some classic cardiovascular risk factors.

\section{Material and Methods}

\section{Study design}

The Mexico City Diabetes Study is a prospective, population-based research designed to describe the prevalence and incidence of diabetes and cardiovascular risk factors in a low-income urban population in Mexico City. Our methods have been described previously. ${ }^{6}$ In summary, the study began in 1989-1990 defining a low-income sector of Mexico City. The study site encompassed six census tracts with a total population of 15532 inhabitants. All 35 to 64 year-old men and non-pregnant women (at time of interview) who permanently resided in the site were considered eligible. We identified 3505 subjects (22.6\%); a home interview was obtained from 3319 (response rate, 94.7\%). At the end of the interview, each participant was invited to undergo a physical and laboratory examination. We performed 2282 exams (response rate, 68.8\%). Two follow-ups were carried out every 3.5 years. After finishing the examination, all participants received a letter with the results of the evaluation. Participants with a specific diagnosis were referred to the physician or institution where they usually receive medical care. A total of 1696 subjects without MI at baseline, corroborated by electrocardiogram (ECG), were included in the present study, after exclusion of 86 subjects with previous MI detected by ECG, 492 without ECG at ba- seline, and eight without follow-up examination. When comparing included and excluded subjects without MI at baseline, we found no differences with regard to sex, BMI, diabetes, serum cholesterol, HDL-cholesterol and triglycerides; however, we observed significant age differences ( 46.9 vs. 48.2 years, respectively), hypertension (18.0 vs. $24.1 \%$, respectively) and current smoking (28.5 vs. $16.6 \%$, respectively).

Current smoking was defined as having at least one cigarette per day in the last year. Body mass index (BMI) was calculated as weight $/$ height $^{2}$ in $\mathrm{kg} / \mathrm{m}^{2}$. Hypertension was defined as systolic blood pressure $(\mathrm{SBP}) \geq 140 \mathrm{mmHg}$, a diastolic blood pressure (DBP) $\geq 90$ $\mathrm{mmHg}$, or treatment with anti-hypertensive drugs. ${ }^{7} \mathrm{~A}$ glucose tolerance test was carried out after an overnight fast and 2-hours after a $75 \mathrm{~g}$ oral carbohydrate. Diabetes was diagnosed as fasting glucose $\geq 126 \mathrm{mg} / \mathrm{dl}$, 2-hour glucose $\geq 200 \mathrm{mg} / \mathrm{dl}$ or treatment with hypoglycemic medication. ${ }^{8}$ Serum cholesterol, high-density level (HDL) cholesterol, triglycerides and fasting insulin levels were also determined. Non-HDL cholesterol (serum cholesterol-HDL cholesterol) was calculated as well.

In subjects without MI at baseline, incident MI was identified through follow-up by ECG or death certificate. An ECG was performed on each participant at every examination. We obtained standard interpretations of each ECG at a reading center that used the Minnesota Code for interpretation (Wake Forest University, EPICARE Center). Codes for possible or probable MI: Q-QS pattern with 1.1-1.2.7, Q-QS and T wave pattern 1.2.8-1.3, and wave T pattern with 5.1-5.3. ${ }^{9}$ We used the death certificate during the time of the study as a criterion when MI was included among the direct or adjacent causes of death in subjects without previous MI on ECG. The cause of death was classified in accordance with the International Classification of Diseases $10^{\text {th }}$ Rev. (ICD $10^{\text {th }}$, codes $\left.410.0-410.9\right) .{ }^{10}$

After the second follow-up examination, all subjects were contacted by phone or visited at their home to confirm if they were still alive. Information on dead subjects was available from family members (wife, husband, daughter, son, sister or brother) who provided either a death certificate or a verbal autopsy.

Laboratory determinations were performed in the research laboratory of the Division of Clinical Epidemiology at the Department of Medicine of the University of Texas Health Science Center at San Antonio, USA. ${ }^{11}$ The Institutional Review Boards of both The University of Texas Health Science Center and the Centro de Estudios en Diabetes approved the study protocol. Each participant gave informed consent. 


\section{Data analysis}

Baseline measurements of the cardiovascular risk factors were used. Incidence was calculated as the number of persons who developed MI divided by person-years of follow-up and expressed per 1000 person-years at risk. The period of risk began at the first research examination in subjects free of MI at baseline and ended when MI was detected at a research examination, at the last examination in subjects who did not develop MI, or at death, whichever came first. Age-standardized rates of MI and their 95\% confidence interval $(95 \% \mathrm{CI})$ were estimated using the direct method, taking the 1995 total Mexican population as a standard population. Serum cholesterol $(<200,200-240$ and $\geq 240 \mathrm{mg} / \mathrm{dL})$ and triglycerides $(<150$ and $\geq 150 \mathrm{mg} / \mathrm{dL}$ ) levels were classified according to standard categories, whereas non-HDL cholesterol (median $154.5 \mathrm{mg} / \mathrm{dL}$ ) and fasting insulin (median $12.5 \mathrm{UI}$ ) levels were divided into lower than their median and equal or higher than their median. Incidence rate ratios (IRRs) assuming Poisson distribution were calculated as well as their $95 \%$ CI. To estimate the association between some classic cardiovascular risk factors and MI, multiple logistic regression analysis was applied. The goodnessof-fit of the model using the Hosmer-Lemeshow test, residuals, and influence statistics were estimated. All analyses were conducted using STATA/SE 9.0 (Stata statistical software: Release 9. College Station. Texas: Stata Corporation, 2005).

\section{Results}

Of 1696 subjects included in this study, $700(41.3 \%)$ were men and 996 (58.7\%) were women. Mean age at the beginning was alike for both men and women. Prevalence of diabetes (men 12.3\%, women 13.3\%) and hypertension (men $15.1 \%$, women $15.9 \%$ ) was also similar for men and women. Current smoking among men was more than twice the proportion among women (42.6 and $18.4 \%$, respectively). The mean non-HDL cholesterol was higher for men, whereas the mean of fasting insulin was higher for women (Table I). Considering diabetes, hypertension, high total serum cholesterol ( $\geq 200 \mathrm{mg}$ ) $\mathrm{dL}$ ), and smoking as major cardiovascular risk factors, $66.1 \%$ of the subjects showed at least one of those, the prevalence being higher for men $(74.1 \%)$ than for women $(60.4 \%)$. As for diabetes and hypertension, $9.6 \%$ of the subjects $(162 / 1696)$ had only the former, $12.3 \%$ (208/1696) had only the latter and 3.3\% (56/1696) had both. Regarding serum cholesterol, $37.5 \%$ of the subjects $(627 / 1671)$ had high levels, and of those, $30.1 \%$ (189/627) also had diabetes and/or hypertension.

During a median follow-up of 6.2 years (range 0.4 10.9 years), 62 subjects ( 30 men and 32 women) experien-

Table I

Baseline Cardiovascular Risk factors for a loW-income popUlation in MeXico City, I989-1997

$\begin{array}{cccc}\text { Cardiovascular risk factor } & \text { Men } & \text { Women } & \text { Both sexes } \\ (n=700) & (n=1696) \\ & \text { No }(\%) & \text { No }(\%) & \text { No }(\%)\end{array}$

\begin{tabular}{|c|c|c|c|}
\hline Age (years) (mean, sd) & $46.8(8.3)$ & $47.0(8.2)$ & $46.9(8.2)$ \\
\hline $\mathrm{BMI}\left(\mathrm{kg} / \mathrm{m}^{2}\right)$ (mean, sd) & $27.2(3.6)$ & $28.8(4.7)^{\S}$ & $28.1(4.3)$ \\
\hline Current smoking & $298(42.6)$ & $183(18.4)^{\S}$ & $48 I(28.4)$ \\
\hline Diabetes* & $86(12.3)$ & $132(13.3)$ & $218(12.9)$ \\
\hline Hypertension & $106(15.1)$ & $158(15.9)$ & $264(15.6)$ \\
\hline Taking antihypertensive drugs & $34(32.1)$ & $100(63.3)^{\S}$ & $134(50.8)$ \\
\hline Serum cholesterol mg/dL (mean, sd) & $192.7(4 \mid .7)$ & I92.I (44.3) & $192.4(43.2)$ \\
\hline Non-HDL cholesterol mg/dL (mean, sd) & I62.8 (4I.I) & I57.5 $(44.2)^{\S}$ & I59.7 (43.0) \\
\hline Triglycerides (mean, sd)\# & $207.4(1.8)$ & $162.2(1.7)^{\S}$ & $179.3(1.7)$ \\
\hline Fasting insulin level IU (mean, sd) & $11.5(2.1)$ & $13.2(2.1)^{\S}$ & $12.5(2.1)$ \\
\hline Taking hypoglucemiant drugs & $66(76.7)$ & $93(70.5)$ & $159(72.9)$ \\
\hline
\end{tabular}

\footnotetext{
* Fasting glucose $\geq 126 \mathrm{mg} / \mathrm{dl}$, 2-hour glucose $\geq 200 \mathrm{mg} / \mathrm{dl}$ or treatment for diabetes

‡ Systolic blood pressure $\geq 140 \mathrm{mmHg}$ or diastolic blood pressure $\geq 90 \mathrm{mmHg}$ or treatment with anti-hypertensive drugs

$\S$ Men vs. women, $\mathrm{p}<0.05$

\# The natural logarithms of triglycerides and fasting insulin levels were used, and later transformed to their original units
}

Missing values: 25 serum cholesterol (16 men, 9 women), 29 non-HDL cholesterol (19 men, 10 women), 27 triglycerides ( 18 men, women 9), 43 fasting insulin (23 men, 20 women) 
ced an MI; 37 were confirmed by ECG (60\%) and 25 by death certificate (40\%). At the end of the follow-up, mean age of subjects with MI was 58.4 years (SD 9.3 years), and that of subjects without MI was 53.6 years (SD 8.1 years) $(p<0.001)$. Mean age at death was lower for men than for women (56.4 versus 60.2 years). Age-specific incidence increased with age for both sexes. Age-adjusted incidence rate for MI was slightly higher, but not significant, for men (6.6 per 1000 person-years) than for women (4.8 per 1000 person-years), with a men-to-women ratio of 1.4:1 (Table II). The age and sex-adjusted IRRs of MI for diabetes, BMI, and serum cholesterol were significant. The incidence of MI in subjects with diabetes was 3.12 (95\% CI 1.83-5.33) times higher than that for subjects without MI. When analyzing separately diabetic and non-diabetic subjects, we found that the IRR of MI was higher for men than for women in both cases, but these differences were not significant (data not shown). Obese subjects had 2.20 (95\% CI 1.00-4.85) times higher risk of suffering a MI than non-obese subjects. For serum cholesterol, a gradient on the IRR was observed, but the IRR was significant only when comparing serum cholesterol $\geq 240 \mathrm{mg} / \mathrm{dL} v$ s. serum cholesterol $<200 \mathrm{mg} /$ dL (IRR 2.78, 95\% CI 1.52-5.09) (Table III).

To estimate the relation between some cardiovascular risk factors and the incidence of MI, a multiple logistic regression model was employed. Subjects with diabetes had a 2.42 (95\% CI 1.35-4.35) times higher risk of developing MI than subjects without diabetes. A 10 $\mathrm{mmHg}$ increase in SBP was associated with 1.28 times (95\% CI 1.05-1.53) the risk of MI. Other variables significantly associated with MI were age $(O R=1.41$ per 5 years, 95\% CI 1.17-1.70) and serum cholesterol $(O R=1.36$ per $50 \mathrm{mg} / \mathrm{dL}, 95 \%$ CI 1.02-1.81). The association between sex, DBP, BMI and anti-hypertensive medications was not significant (Table IV).

\section{Discussion}

The data shown in this study are the first of its kind obtained from a Mexican population. The incidence rate of MI accords with the high prevalence of classic cardiovascular risk factors among this population, such as diabetes, hypertension, and dyslipidemia. ${ }^{12-14}$ Also, the 2000 National Health Survey in Mexico ${ }^{15}$ confirmed the high prevalence, at a national level, of the cardiovascular risk factors mentioned previously. Compared to Mexican-Americans, a high frequency of fatal and nonfatal MI among Mexicans has been explained, in part, by access to health care. ${ }^{16}$ As for mortality, cardiovascular diseases are the main general cause of death in Mexico, and coronary heart disease (CHD) is the most common condition among those (first cause of death for men and second cause of death for women). ${ }^{17}$

In the present study, $66.1 \%$ of the participants had at least one of the four major cardiovascular risk factors: diabetes, hypertension, hypercholesterolemia or smoking, regardless of obesity. However, only diabetes, SBP, and serum cholesterol were associated with the incidence of MI. With respect to the frequency of some cardiovascular risk factors from the NHANES III, a higher prevalence of elevated blood pressure $(62.5 \%)$, obesity (55.0\%), triglycerides (42.8\%), HDL cholesterol (39.5\%) and fasting glucose (27.2\%) was reported. Nevertheless, only diabetes and HDL cholesterol were associated with the prevalence of $\mathrm{CHD}$ in that population. ${ }^{18}$

The associated risk factors identified in the incident cases in this study coincide with the traditional cardiovascular profile model. ${ }^{19-22}$ We should underscore the high lethality of cardiovascular diseases, specifically MI, conferred by several classic cardiovascular risk factors among both men and women. ${ }^{1,23,24}$ It should also be noted that, similar to other populations, ${ }^{1,3,23}$ women

Table II

NuMBER OF CASES AND AGE- AND SEX-SPECIFIC MYOCARDIAL INFARCTION INCIDENCE RATES FOR A LOW-INCOME POPULATION IN MEXICO CITY, I 989-I 997

\begin{tabular}{|c|c|c|c|c|c|c|c|c|c|}
\hline \multirow[b]{2}{*}{ Age (years) } & \multicolumn{3}{|c|}{ Men } & \multicolumn{3}{|c|}{ Women } & \multicolumn{3}{|c|}{ Both sexes } \\
\hline & Person-years & No. Cases & Incidence* & Person-years & No. Cases & Incidence* & Person-years & No. Cases & Incidence* \\
\hline $35-44$ & 2019.2 & 8 & 4.0 & 2792.7 & 6 & 2.1 & 4811.9 & 14 & 2.9 \\
\hline $45-54$ & 1499.9 & 8 & 5.3 & 2198.9 & 7 & 3.2 & 3698.8 & 15 & 4.1 \\
\hline $55-64$ & 925.2 & 14 & 15.1 & 1336.7 & 19 & 14.2 & 2261.9 & 33 & 14.6 \\
\hline Crude & 4444.3 & 30 & 6.8 & 6328.3 & 32 & 5.1 & 10772.7 & 62 & 5.8 \\
\hline Age-adjusted & - & 30 & 6.6 & - & 32 & 4.8 & - & 62 & 5.5 \\
\hline * Per I 000 person & & & & & & & & & \\
\hline
\end{tabular}


Table III

Crude and age- and SeX-Adjusted myocardial infarction InCidence rate and incidence rate Ratio (IRR) FOR A LOW-INCOME POPULATION IN MEXICO CITY, 1989-1997

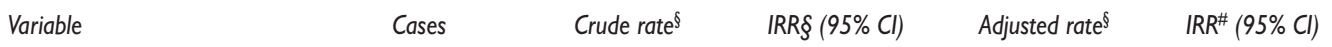

BMI

\begin{tabular}{llllll}
$\geq 25 \mathrm{~kg} / \mathrm{m}^{2}$ & 55 & 6.6 & $2.30(1.05-5.06)$ & 6.4 & $2.20(1.00-4.85)$ \\
\hline$<25 \mathrm{~kg} / \mathrm{m}^{2}$ & 7 & 2.9 & & 2.9 &
\end{tabular}

Current smoking

\begin{tabular}{llllll} 
Yes & 14 & 4.6 & $0.73(0.4 I-1.33)$ & 4.5 & $0.72(0.39-1.34)$ \\
\hline No & 48 & 6.2 & & 6.1 &
\end{tabular}

Diabetes status*

\begin{tabular}{llccccc} 
Yes & 22 & 16.1 & $3.80(2.26-6.39)$ & 14.2 & $3.12(1.83-5.33)$ \\
\hline No & 40 & 4.3 & & 4.3 &
\end{tabular}

Hypertension ${ }^{\ddagger}$

\begin{tabular}{lllllll} 
Yes & 16 & 9.6 & $1.91(1.08-3.37)$ & 8.5 & $1.52(0.85-2.72)$ \\
\hline No & 46 & 5.0 & & 5.2 &
\end{tabular}

Serum cholesterol

\begin{tabular}{llllll}
$<200 \mathrm{mg} / \mathrm{dL}$ & 28 & 4.2 & 1.0 & 4.2 & 1.0 \\
\hline $200-239 \mathrm{mg} / \mathrm{dL}$ & 14 & 5.3 & $1.25(0.66-2.37)$ & 4.9 & $1.13(0.59-2.15)$ \\
\hline$\geq 240 \mathrm{mg} / \mathrm{dL}$ & 17 & 12.8 & $3.04(1.66-5.56)$ & 13.6 & $2.78(1.52-5.09)$
\end{tabular}

Non-HDL cholesterol (median $154.5 \mathrm{mg} / \mathrm{dL}$ )

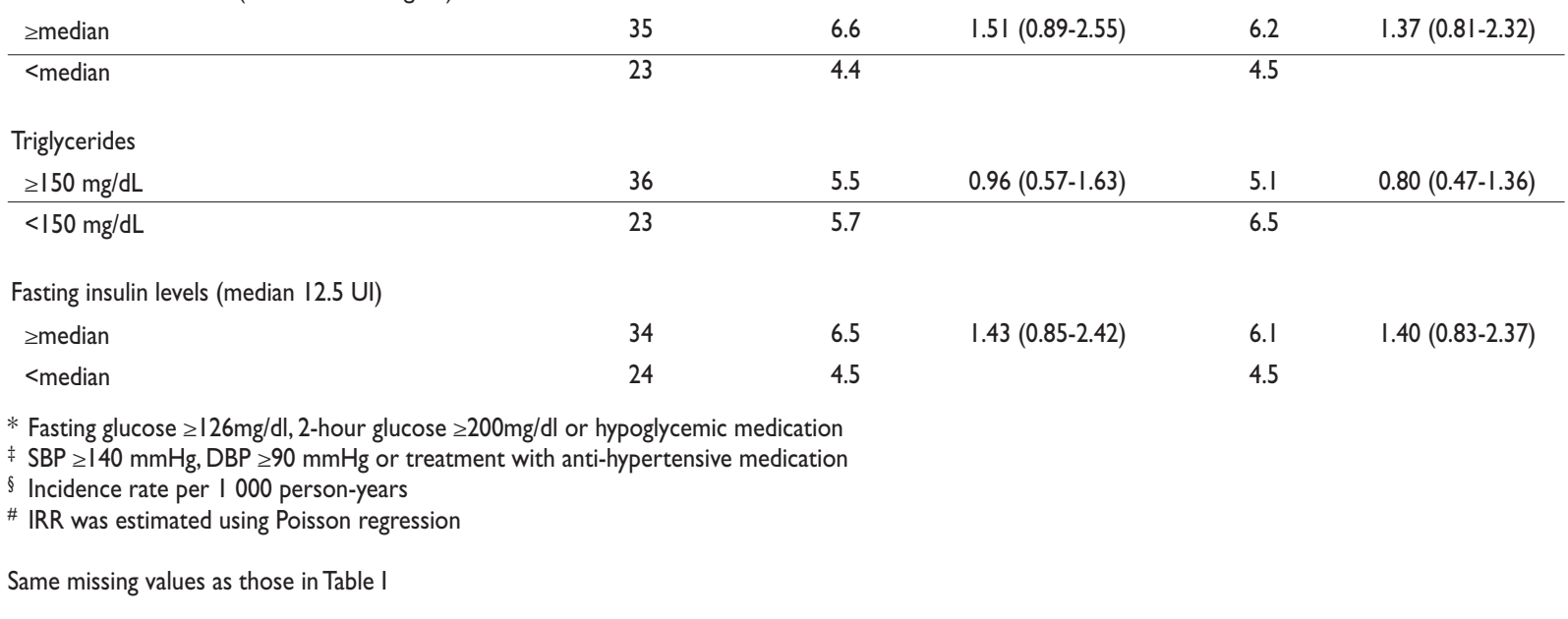

had a lower cardiovascular risk profile than men, which was associated with a lower incidence of MI in younger women. ${ }^{3,12}$ However, we observed that the incidence for older women was basically the same as that for men (14.5 vs. 15.4 per 1000 person-years, respectively), which may be accounted for by the rising prevalence in recent years of some risk factors among women.
In this study, diabetes but not insulin levels was significantly associated with the incidence of MI after adjustment for other cardiovascular risk factors. As for other populations, men had a greater risk of developing MI than women, whereas for subjects with diabetes the risk was similar for both men and women, thus the difference between sexes may be due, in part, 
Table IV

MULTIPLE LOGISTIC REGRESSION ANALYSIS FOR MYOCARDIAL INFARCTION INCIDENCE IN A LOW-INCOME population in MeXico City, I989-1997

OR $(95 \% \mathrm{Cl})$

Model covariates

(I 67 I subjects, 59 cases) p value

\begin{tabular}{|c|c|c|}
\hline Age per 5 years & $1.4 \mathrm{I}(1.17-1.70)$ & $<0.001$ \\
\hline Men & $1.64(0.93-2.92)$ & 0.090 \\
\hline BMI per $5 \mathrm{~kg} / \mathrm{m}^{2}$ & $1.16(0.86-1.58)$ & 0.324 \\
\hline SBP per $10 \mathrm{mmHg}$ & $1.28(1.05-1.53)$ & 0.013 \\
\hline DBP per $10 \mathrm{mmHg}$ & $0.73(0.52-1.03)$ & 0.074 \\
\hline Anti-hypertensive treatment & $1.20(0.5 \mid-2.79)$ & 0.675 \\
\hline Diabetes* & $2.42(1.35-4.35)$ & 0.003 \\
\hline Serum cholesterol per $50 \mathrm{mg} / \mathrm{dL}$ & $1.36(I .02-1.8 I)$ & 0.038 \\
\hline
\end{tabular}

to the diabetes effect. ${ }^{25}$ It has been documented as well that the risk of CHD mortality due to diabetes in absence of cardiovascular disease is similar to that associated with a history of MI without diabetes. ${ }^{26,27}$ Additionally, we found differences in the proportion of fatal and non-fatal MI among subjects with $(16 / 22)$ and without type 2 diabetes $(9 / 40)$, and fatal cases were overrepresented in the former, thus the worst cardiovascular profile in subjects with diabetes is strongly related to mortality from MI.

An increased risk of developing MI was significantly associated with serum cholesterol levels $\geq 240$ $\mathrm{mg} / \mathrm{dL}$. A graded positive relation between serum cholesterol and CHD has been shown in several populations, whereas a protective effect of HDL cholesterol has been reported, particularly among women. ${ }^{28}$ No significant association was found between MI and BMI after adjusting for other cardiovascular risk factors. Obesity in other populations clearly increased the risk of cardiovascular disease regardless of other risk factors; however, obesity is a better predictor of cardiovascular disease for women and for younger people. ${ }^{26,29} \mathrm{SBP}$ but not hypertension in this population was associated with MI, possibly because of recent hypertension diagnosis in some cases. Both hypertension and its control have been shown to be related to CHD mortality in subjects with and without diabetes. 26,30

We have attempted to maintain rigorous methodology and diagnostic criteria during the study. An expert panel interpreted the ECGs using internationally accepted procedures. Our fieldwork enabled us to maintain reasonable follow-up of our population. However, because of the number of subjects without baseline ECG, we may be underestimating the true incidence of MI. In addition, because MI cases defined by ECG did not include clinical information, this could introduce a misclassification bias; the assumption was that we reduced the bias because all subjects were free of MI at baseline. To ascertain vital status, all subjects were contacted to confirm whether they were still alive. If the participant had died, we obtained the death certificate from a family member or from the institution (which provided the certificate).

We concluded that the incidence of MI was similar for both men and women after adjustment for age. While MI is often lethal, the most commonly associated major cardiovascular risk factors are all amenable to viable, previously proven, successful public health interventions that should diminish its high impact on the population. Current general and specific recommendations must be exhaustively implemented to substantially decrease classic cardiovascular risk factors for specific risk groups.

\section{Acknowledgments}

The authors would like to thank the residents of the neighborhoods who participated in the study. The Research Grant RO1HL 24799 of the National Heart Lung and Blood Institute, Bethesda, MD, USA, supported this work. Funding from The Consejo Nacional de Ciencia y Tecnologia, CONACYT, Grants 2092/ M9303, F677M9407, 3502-M9607 also helped in some parts of the study. The Fundacion Mexicana para la Salud provided administrative support as well.

\section{References}

I. Kirchhoff M, Davidsen M, Brønnum-Hansen H, Hansen B, Schnack $\mathrm{H}$, Eriksen $\mathrm{LS}$, et al. Incidence of myocardial infarction in the Danish MONICA population 1982-1991. Int J Epidemiol 1999;28:21 I-218 2. Jones DW, Chambless LE, Folsom AR, Heiss G, Hutchinson RG, Sharrett AR, et al. ARIC. Risk factors for coronary disease in African-Americans. The Atherosclerosis Risk in Communities Study 1987-1997.Arch Intern Med 2002; 162:2565-257|

3. Lee WL, Cheung AM, Cape D, Zinman B. Impact of diabetes on coronary artery disease in women and men:A meta-analysis of prospective studies. Diabetes Care 2000;23:962-968

4. Pérez G, Pena A, Sala J, Roset P, Masiá R, Marrugat J.Acute myocardial infarction case fatality, incidence and mortality rates in a population registry in Gerona, Spain, 1990-1992. REGICOR Investigators. Int J Epidemiol 1998; 27:599-604

5. Rosamond WD, Chambless LE, Folsom AR, Cooper LS, Conwill DE, $C$ legg $L$, et al. Trends in the incidence of myocardial infarction and in mortality due to coronary heart disease, 1987 to 1994. N Engl J Med 1998; 24:861-867 
6. Stern MP, Gonzalez C, Mitchell BD,Villalpando E, Haffner SM, Hazuda HP. Genetic and environmental determinants of type II diabetes in Mexico City and San Antonio. Diabetes 1992; 41:484-492

7.Chobanian AV, Bakris GL, Black HR, Cushman WC, Green LA, Izzo JL Jr, et al. The Seventh Report of the Joint National Committee on Prevention, Detection, Evaluation and Treatment of High Blood Pressure. JAMA 2003; 289:2560-2572

8. World Health Organization Study Group on Diabetes Mellitus. Diabetes Mellitus.WHO Technical Reports No. I27. Geneva, Switzerland:WHO, 1985.

9. Prineas R, Crow R, Blackburn H. The Minnesota Code Manual of Electrocardiographic Findings. Littleton, MA: John Wrigth-PSG, Inc, 1982. 10. Organizacion Panamericana de la Salud. Clasificacion Estadistica Internacional de Enfermedades y Problemas Relacionados con la Salud. Scientific Publication 554. I0ed, 3 vols. Washington DC:OPS, 1995. II. Haffner SM, Stern MP, Gonzalez-Villalpando C. A Prospective analysis of the HOMA model:The Mexico City Diabetes Study. Diabetes Care 1996; |9:||38-| |4|

12. Gonzalez-Villalpando C, Stern MP,Villalpando E. Prevalence of diabetes and glucose intolerance in an urban population at a low-economic level. Rev Invest Clin I992 44:32I-28

13. Haffner S, Gonzalez-Villalpando C, Hazuda HP. Prevalence of hypertension in Mexico City and San Antonio, Texas. Circulation 1994; 90:1542-1549

14. Gonzalez-Villalpando C, Stern MP,Arredondo-Perez B. Undiagnosed hypercholesterolemia:A serious health challenge. The Mexico City Diabetes Study.Arch Med Res 1996; 27:19-23

15. Velazquez-Monroy O, Rosas-Peralta M, Lara-Esqueda A. Prevalence and interrelations of non-communicable chronic diseases and cardiovascular risk factors in Mexico. Final outcomes from the National Health Survey 2000 Arch Cardiol Mex 2003; 73:62-77

16. Mitchell BD, González Villalpando C,Arredondo Pérez B, García MS, Valdez R, Stern MP. Myocardial infarction and cardiovascular risk factors in Mexico City and San Antonio, Texas. Arterioscler Thromb Vasc Biol 1995; 15:72I-725.

17. Velazquez-Monroy O,Velásquez-Monroy O, BarinagarrementeríaAldatz FS, Rubio-Guerra AF,Verdejo J, Méndez-Bello MA, et al. Morbilidad y mortalidad de la enfermedad isquémica del corazón y cerebrovascular en Mexico. 2005. Arch Cardiol Mex 2007; 77:31-39

18. Alexander CM, Landsman PB, Teutsch SM, Haffner SM. NCEP-defined metabolic syndrome, diabetes, and prevalence of coronary heart disease among NHANES III participants age 50 years an older. Diabetes 2003; $52: 1210-1214$
19. Mitchell BD, Stern MP, Haffner SM. Risk factors for cardiovascular mortality in Mexican-Americans and non-Hispanic whites:The San Antonio Heart Study. Am J Epidemiol 1990; |31:423-433.

20. Greenlee RT, Naleway AL,Vidaillet H. Incidence of myocardial infarction in a general population:The Marshfield Epidemiologic Study Area.WMJ 2002;101:46-52.

2I. Bobak M, Hense HW, Kark J, Kuch B,Vojtisek P, Sinnreich R, et al. An ecological study of determinants of coronary heart disease rates: $A$ comparison of Czech, Bavarian and Israeli men. Int J Epidemiol 1999; 28: 437-444

22. Folsom AR, Chambless LE, Duncan BB, Gilbert AC, Pankow JS. Prediction of coronary heart disease in middle-aged adults with diabetes. Diabetes Care 2003;26:2777-2784

23. Lowe LP, Greenland P, Ruth KJ, Dyer AR, Stamler R, Stamler J. Impact of major cardiovascular disease risk factors, particularly in combination, on 22-year mortality in women and men. Arch Intern Med 1998; 158 : 2007-20I4

24. Turner RC, Millns H, Neil HA, Stratton IM, Manley SE, Matthews DR. Risk factors for coronary artery disease in non-insulin dependent diabetes mellitus: United Kingdom Prospective Diabetes Study (UKPDS: 23). BMJ 1998; 316:823-828

25. Stevens RJ, Kothari V,Adler AI, Stratton IM.The UKPDS risk engine: a model for the risk of coronary heart disease in Type II diabetes (UKPDS

56). Clin Sci 200I;I0I-67I-379

26. Lotufo PA, Gaziano JM, Chae CU,Ajani UA, Moreno-John G, Buring JE. Diabetes and all-cause mortality and coronary heart disease mortality among US male physicians. Arch Intern Med 2001;161:242-247

27. Haffner SM, Lehto S, Rönnemaa T, Pyörälä K, Laakso M. Mortality from coronary heart disease in subjects with type 2 diabetes and in nondiabetic subjects with and without prior myocardial infarction. N Engl J Med 1998; 339:229-234

28. Neaton J,Wentworth D. Serum cholesterol, blood pressure, cigarette smoking, and death from coronary heart disease. The Multiple Risk Factor Intervention Trial Research Group. Arch Intern Med 1992;152:56-64. 29. Hubert HB, Feinleib M, McNamara PM, Castelli WP. Obesity is an independent risk factor for cardiovascular disease: a 26-year follow-up of participants in The Framingham Heart Study. Circulation 1983; 67:968-977 30. Sievers ML, Bennett PH, Roumain J, Nelson RG. Effect of hypertension on mortality in Pima Indians. Circulation 1999;100:33-40 